\title{
THE ASSOCIATION OF GENETIC POLYMORPHISMS WITH DIABETES MELLITUS TYPE 1
}

\author{
Maja Jović1, Vesna Cvetkovićn ${ }^{3}$ Milena Despotović2 ${ }^{2}$ Tatjana Jevtović-Stoimenov ${ }^{1,2}$
}

\begin{abstract}
One of the most common endocrine disorders in children and adolescents, Diabetes mellitus (DM), is a chronic, polygenic and complex illness. Based on etiology, DM can be divided into two basic groups: Diabetes mellitus type 1 (DMT1) and Diabetes mellitus type 2 (DMT2). DMT1 is a disease mediated by immune mechanisms based on the autoimmune destruction of insulocyte by immunoreactive $\mathrm{T}$ cells and antibodies which leads to insulin resistance and hyperglycemia syndrome.

Several different molecular mechanisms contribute to the destruction of $\beta$-cells of Langerhans islets, such as: the production of autoantibodies directed against antigens on insulocytes, lysis of Langerhans islets mediated by cytotoxic CD8+ T lymphocytes, local production of cytokines (TNF and IL-1) by macrophages that damage insulocytes and delayed hypersensitivity reactions mediated by CD4+ Th1 lymphocytes.

The most important genes that show a high degree of association with DMT1 are found in the region which encodes MHC (major histocompatibility complex) of molecules class I and II. However, there is very strong evidence of association of other genes (outside of the MHC gene domain) with the expression of DMT1. These are: insulin gene (INS), Cytotoxic TLymphocyte Associated Protein 4 (CTLA4), Protein Tyrosine Phosphatase Non-Receptor Type 22 (PTPN22), Protein Tyrosine Phosphatase Non-Receptor Type 2 (PTPN2), C-type lecithin gene (CLEC16A, KIAA0350), interleukin 2 receptor a gene (IL2RA/CD25), interferon-induced helicase gen domain (IFIH1), Potassium Voltage-Gated Channel Subfamily J Member 11 (KCNJ11), Platelet and T Cell Activation Antigen 1 (CD226), vitamin D receptor gene (VDR), tumor necrosis factor gene (TNF) and lymphotoxin-a (LTA). In addition to these genes, researchers are still searching for other genes that are associated with the appearance and expression of DMT1.
\end{abstract}

Acta Medica Medianae 2020;59(1):125-132.

Key words: Diabetes mellitus type 1, autoimmune endocrinopathy, non-HLA gene polymorphisms

${ }^{1}$ University of Niš, Faculty of Medicine, Research Center for Biomedicine, Niš, Serbia

${ }^{2}$ University of Nišs, Faculty of Medicine, Department of Biochemistry, Niš, Serbia

${ }^{3}$ Pediatric Internal Diseases Clinic, Clinical Center Niš, Serbia

Contact: Maja Jović

81 Dr. Zoran Djindjić Blvd., 18000 Niš, Serbia

E-mail: drmajaj@gmail.com

\section{Diabetes mellitus type 1}

Diabetes mellitus type 1 (DMT1) is an immune-mediated disease based on the autoimmune destruction of Langernahs pancreatic insulocytes by immunoreactive $T$ cells and antibodies, resulting in a progressive decrease in the number of insulocytes and their ability of insulin secretion leading to insulin resistance and hyperglycemia syndrome. This chronically progressive autoimmune disease occurs in a person with a genetic predisposition to its development. The first symptoms of this disorder most commonly occur early in childhood while the disease appears in puberty and progresses with age. According to the classifications given by the World Health Organization (WHO) and ADA, there are two types of DMT1. The more common type $(1 \mathrm{~A})$ belongs to autoimmune diseases of complex etiology, while the rare type (1B) is characterized by idiopathic etiology. Both types are characterized by the destruction of $\beta$-cells Langerhans's isles in the pancreas in genetically predisposed individuals. This occurs under the influence of infectious or toxic environmental factors which consequently leads to a lack of insulin. Based on the appearance of typical symptoms of the disease (polydipsia, polyuria, polyphagia), and the presence of elevated blood glucose levels, the diagnosis of DMT1 is established. 
Complications of DMT1 have been common including macroangiopathies, such as progressive atherosclerosis of the arteries leading to ischemic sclerosis of the extremities and internal organs and microangiopathy, i.e., microvascular obstructions leading to damage of the retina, renal glomeruli, and peripheral nerves. All mentioned complications of DMT1 can lead to renal and cardiovascular disease, blindness, and early death of adults, the insulin therapy is necessary both for disease control and for prolonging the life age. Most people with DMT1 depend on external insulin compensation and without insulin, they develop severe metabolic complications such as acute ketoacidosis and coma $(1,2)$.

\section{Etiopathogenesis of DMT1}

The mutual action of certain genetic, immunological and environmental factors leads to the initiation of the process that will affect the destruction of type B insulocytes. Environmental factors include viral infections (cytomegalovirus, mumps, rubeola, coxsackievirus), early infant feeding with cow's milk, additives (nitrosamines) and toxins in food. External factors include climate change, stress and vaccination. These factors can represent a trigger for the occurrence of DMT1. Viruses, for example, promote the development of DMT1 mainly by molecular mimicry (GAD - the glutamic acid decarboxylase antigen on type B insulocytes and Coxsackie B4 virus have similar molecular properties) or non-specific cytokine-mediated reactions. The onset of diabetes is also affected by the secretion of certain hormones within physiological limits. The highest incidence of this type of diabetes is from 11 to 13 years of age when the growth hormone is most secreted as well as sex hormones that have the effect opposite to insulin (3-5).

There are several molecular mechanisms that contribute to the destruction of the $\beta$-cells of the Langerhans islets. The most important of these are:

a) production of autoantibodies directed against antigens on insulocytes,

b) lysis of Langerhans's islets mediated by cytotoxic CD8+ T lymphocytes,

c) local production of cytokines (TNF or IL-1) by macrophages that damage the insulocytes,

d) delayed-hypersensitivity mediated by $\mathrm{CD} 4+$ Th1 lymphocytes that are reactive to insulocyte antigen (including insulin) $(6,7)$.

\section{of DMT1}

Genetic factors that affect the appearance

DMT1 is a complex, genetically determined disease whose development and manifestation also depends on environmental factors. Genes that can lead to this disease are found in 60 chromosomal regions. The most important genes that show a high degree of association with DMT1 are found in the region that encodes the MHC (major histocompatibility complex) class II molecule located on the $6 \mathrm{p} 21$ (HLA-D) chromosome, as well as the genes for MHC class I molecule. MHC genes are designated in humans as HLA (human leukocyte antigen) genes. Besides these, there are other genes that are associated with the manifestation of DMT1, but the evidence of their association is still investigated. These are: $5^{\prime}$ end of insulin gene (INS), gene for protein 4 linked to cytotoxic T lymphocyte (CTLA4), gene for protein tyrosine phosphatase - 22 (PTPN22), gene for protein tyrosine phosphatase - 2 (PTPN2), gene for protein lecithin type C (CLEC16A, known as KIAA0350), gene for receptor of a interleukin 2 (IL2RA/CD25), gene region of interferoninduced helixase (IFIH1), KCNJ11, CD226, gene for vitamin $D$ receptor (VDR), genes for tumor necrosis factor (TNF) and lymphotoxin-a (LTA) and gene regions on chromosomes 12q24, 12q13, 16p13 and 18p11. In addition to these genes, researchers are still searching for other genes that are associated with the appearance and expression DMT1 $(2,7,8)$.

\section{Human leukocyte antigen}

The HLA system plays an important role in human immune responses. There are three classes of HLA systems with their corresponding functions: HLA I (HLA-A, HLA-B and HLA-C), HLA II (HLA-DR, HLA-DQ and HLA-DP) and HLA III. The genes HLA class I and II encode molecules that have a major role in the treatment and presentation of antigen by T lymphocytes $(9,10)$.

The HLA region of chromosome 6 is responsible for nearly $50 \%$ of the genetic predisposition to the development of DMT1. The subregions of DR4 and DR3 HLA class II are strongly related to the occurrence of DMT1 and the combination of DR3 / DR4 allele multiplies the risk of illness. It is believed that haplotype combinations of class II of the HLA gene DR4-DQB1-0302 and DR3-DQB1*0201 are the main markers of the tendency towards this disease. About $90 \%$ of children with DMT1 are carriers of one or both of these haplotypes of the gene. It is known that about $95 \%$ of Caucasians with DMT1 are wearing HLA-DR3, DR4 or both antigens. In carriers of DR3 and DR4 antigens, the risk of developing this disease is increased tenfold $(2,3,9)$.

\section{Gene for insulin (INS)}

Insulin has a major role in the clinical, genetic and immunological aspects of DMT1. Gene for insulin is localized to $11 \mathrm{p} 15$ chromosome. This gene encodes a protein, pre-proinsulin, consisting of 110 amino acids, which is synthesized by beta cells of the Langerhans's islets. By reaction of proteases that eliminate the signal peptide pre-proinsulin is modified to proinsulin which is transformed into biologically active insulin after splitting of the C-peptide $(11,12)$.

The insulin gene locus is the second most important locus after the HLA locus which indicates a predisposition to the development of DMT1. The insulin gene comprises 3 exons and 2 introns, separated from each other by several polymorphisms in linkage disequilibrium (LD). The insulin locus represents a variable number of tandem repeats (VNTR) 
in the INS gene promoter. The alleles of this region are divided into three classes, I, II and III. Alleles class I contain about 570 base pairs (bp) (26-63 repeats), allele class II have 1200 base pairs (around 80 repeats) and allele class III have 2200 base pairs (140-210 repeats). Studies have shown that allele class I are associated with a higher risk of developing DMT1 than allele class III that are considered to have a protective role (13-15).

The genetic susceptibility mechanism is explained in such a way that the own antigens for allele class I are less expressed in thymus compared to own antigens for allele class III that are two to three times more expressed in the thymus. This will affect the positive and negative selection of $T$ lymphocytes in the thymus. There is the inverse pattern of expression in the pancreas $(16,17)$.

\section{Gene for protein 4 associated with cytotoxic T-lymphocyte antigen-4 (CTLA4)}

CTLA-4 gene is located on chromosome 2 q33. It encodes the homonymous molecule localized on the surface of activated T-lymphocytes which is responsible for suppressing the immune response. Inactive T-lymphocytes do not express CTLA-4 on their surface while when activating T-lymphocytes this molecule binds to the receptor on antigen presenting cells (APC), which stops activation of T-lymphocyte thereby interrupting the immune response. The CTLA-4 binding to the APC receptor creates an inhibitory signal for the production of IL-2 and IL-2 receptors, as well as the continuation of the cell cycle. In this way, CTLA-4 plays an important role in the regulation of lymphocytic expansion which leads to a gradual reduction of the immune response. Changes in the expression of the gene for CTLA4 can lead to an increase in the autoreactivity or reactivity of T-lymphocytes, which may affect the onset of autoimmune diseases such as DMT1 (18, 19).

The onset of many other autoimmune diseases is associated with the mutation of the CTLA-4 gene. Mutation of this gene can cause asthma, Addison's disease, myasthenia gravis, Sjogren's syndrome, systemic lupus erythematosus, systemic sclerosis, ulcerative colitis and thyroiditis (20-23).

The following polymorphisms of the CTLA-4 gene have shown the association with DMT1: 49A/G in exon 1, CT60 in 3' UTR (untranslated region), $318 \mathrm{C} / \mathrm{T},-1661 \mathrm{~A} / \mathrm{G} \mathrm{i}-1722 \mathrm{C} / \mathrm{T}$ in the promoter region. Several studies in which the polymorphism of CTLA-4 gene was showed that the greatest association with DMT1 shows allele $G$ polymorphism 49A/G of CTLA-4 gene. The SNP CTLA-4 gene is associated with the symptoms of DMT1 in several human populations $(19,24,25)$.

\section{2 (PTPN22)}

Gene for protein tyrosine phosphatase-

Gene for PTPN22 is localized to chromosome 1p13.3-13.1. This gene encodes lymphoid tyrosine phosphatase (LYP) which inhibits the proliferation and activation of T-lymphocytes (26). LYP in interaction with Csk, C-terminal tyrosine kinase, reduces signal transduction via TCR (T-cell receptor), thus regulating various cellular activities including cell growth, differentiation, division and apoptosis. The polymorphism at position 1858 within this gene, when cysteine is replaced by thymine leads to a mutation at the codon 620 for LYP. This mutation leads to the loss of interaction between LYP and Csk which creates conditions for inadequate prolonged activation of T-lymphocytes leading to autoimmunity and the possibility of DMT1 $(8,19)$.

The variant of PTPN22 R620W is associated with multiple autoimmune diseases such as lupus erythematosus, rheumatoid arthritis, juvenile idiopathic arthritis, multiple sclerosis, autoimmune thyroiditis, psoriasis and Addison's disease, as confirmed by more studies in Europe and the United States $(27,28)$.

\section{Gene for the a interleukin 2 receptor (IL2RA/CD25)}

The CD25 gene is located on chromosome $10 p 15$. This gene encodes the a-chain IL-2 receptor which is expressed for several hours after antigen activation on CD4+ and CD8+, as well as on regulatory T-lymphocytes. Only after the formation of the third subunit of the IL-2 receptor (a-chain) this receptor can bind IL-2. IL-2 generates the same cells that this interleukin acts through its receptor. IL-2 is also referred to as T-lymphocyte growth factor, because its basic activity is stimulation of Tlymphocyte proliferation, that is, the stimulation of the entry of T-lymphocytes into the cell cycle and their consequent division. This leads to an increase in the number of antigen-specific T-lymphocytes. Expression of CD25 on regulatory T-lymphocytes is an important factor in suppressing the T-cell immune response and consequently also on the protection against the onset of autoimmune diseases. However, mutations on this gene in humans lead to severe forms of autoimmune diseases, including DMT1 $(8,29)$.

\section{The genetic region for interferon-induced helicase (IFIH1)}

The genetic region for interferon-induced helicase (IFIH1) is located on chromosome 2 q24. IFIH1 encodes cytoplasmic viral sensor melanoma differentiation associated protein 5 (MDA5). After viral infection, MDA5 binds to viral RNA chains activating transcriptional factors (IRF7, IRF3, IRF1 and $\mathrm{NFKB}$ ) which induce the formation and secretion of several proinflammatory factors, interferons and interleukins: INF-a, INF- $\beta$, INF- $y$ IL-1, IL-6, IL-8. Proinflammatory cytokines activate NK and T-lymphocytes, then attract dendritic cells, macrophages, and granulocytes to the site of infection leading to the destruction of beta cells of the pancreas. In this way, the presentation of the own antigens of the pancreatic beta cells to the immune system is increased resulting in an autoimmune reaction, which 
is a trigger for the development of DTM1. This confirms the fact that viruses can contribute to the initiation of DMT1 $(27,30)$.

Several polymorphisms of IFIH1 gene locus, rs1990760 or Thr946Ala, rs2111485, rs3747517, and rs13422767, are associated with the emergence of DMT1 (31).

\section{Gene for vitamin D receptor (VDR)}

DMT1 is a common autoimmune endocrinopathy in which the deficiency of Vitamin $D$ can be one of the causes of its initiation. It has been shown that the application of 1,25-dihydroxy vitamin D3, in the experimental model of animals suffering from Tcell-dependent autoimmune diabetes reduces the incidence of this disease. The way in which disease progression is stopped is not yet fully clarified but there is evidence of cytokine modulation of $T$ helper (Th1/Th2) lymphocyte balance in local pancreatic lesions. Recent studies show that a significant pathophysiological role in the onset of diabetes mellitus has a specific vitamin D (VDR) nuclear receptor, which is particularly expressed on monocytes and activated T-lymphocytes. By binding the ligand to VDR receptor there is a decrease in secretion of cytokines (IL-1, IL-2, IL-6, IL-12, TNF, and interferon- $\gamma)(32,33)$ involved in the pathogenesis of autoimmune diseases. In this regard, it has been shown that VDR receptor polymorphism has an effect on the occurrence of DMT1 $(34,35)$.

The VDR gene is localized to a long arm of chromosomes 12 and 14. Although there are many polymorphisms of this gene only four SNPs have been tested so far:

- Bsm1 (rs1544410),

- Fok1 (rs10735810),

- Apa1 (rs7975232) and

- Taq1 (rs731236).

All of the aforementioned polymorphisms are associated with some of the autoimmune disorders in humans, such as celiac disease, multiple sclerosis, systemic lupus erythematosus, rheumatoid arthritis and Hashimoto thyroiditis $(36,37)$.

\section{Genes for tumor necrosis factor (TNF) and lymphotoxin-a (LTA)}

The tumor necrosis factor (TNF) is a proinflammatory cytokine. It belongs to TNF superfamily of cytokines. It is also marked as TNF-a, to differ from TNF- $\beta$, which is also called lymphotoxin (LTA). Cells which secrete TNF are activated phagocytes, antigen-stimulated T-lymphocytes, NK cells and mastocytes (35).

There are two types of TNF molecules, membrane, and secretion. Membrane TNF (mTNF) is a non-glycose type II membrane protein with the intracellular amino-terminal end and a large extracellular carboxy-terminal end. Secretory TNF (STNF) has a triangular pyramidal shape where each side of the pyramid forms on a subunit of this molecule. Biologically active forms are trimer forms of protein, homotrimer $(23,38)$.
Biological functions of TNF are carried out over two types of external membrane receptors TNFR1 and TNFR2. By binding the ligand to the receptors, signal pathways for apoptosis are activated, nuclear kappa factor B (NF-kappa B), ERKkinase, p38 protein kinase, and $\mathrm{C}$-Jun- $\mathrm{N}$-terminal kinase. The biological effects are stimulation of migration and activation of leukocytes at the site of infection, induction of expression of adhesion molecules (selectins and integrins) on endothelial cells, inhibition or induction of apoptosis. TNF also works on macrophages, stimulating them to produce IL-1, which has a similar role to $\operatorname{TNF}(29,35,38,39)$

The TNF encoding genes are located on a short arm of chromosome 6, in class III of the MHC locus, between the HLA-B and the HLA-DR gene. It has been proven that there is a strong bond between THF allele with DR haplotypes, such as HLA-A1-B8-DR3 and Bw62-DR4. Both alleles are expressed in patients with DMT1. The most researched TNF polymorphisms associated with DMT1 are rs1800629 (at position 308) and rs361525 (at position 238) (40).

\section{Gene CLEC16A and gene for protein tyrosine phosphatase-2 (PTPN2)}

Gene CLEC16A (C-type lectin domain family 16, also known as KIAA0350) is localized on chromosome $16 \mathrm{p} 13$ and encodes a protein with $\mathrm{Ca}+$ dependent or type $\mathrm{C}$ lectin binding structure. This protein plays important roles in binding carbohydrates, cell adhesion, and pathogen recognition. KIAA0350 is almost exclusively expressed in cells of the immune system (dendritic cells, NK cells, B lymphocytes). These cells are crucial in the pathogenesis of DMT1 which indicates that modulation of immunity contributes to the onset of disease. Several polymorphisms of the KIAA0350 gene (rs2903692, rs725613, rs17673553 and 12708716) are associated with the occurrence of multiple sclerosis and DMT1 $(29,41)$.

PTPN2 (also known as TC-PTP or PTP-S2) gene, which is localized on chromosome 18, encodes tyrosine phosphatase 2 which is a negative regulator of inflammatory processes and is particularly present in immune system cells (CD4+ T-lymphocytes and B-lymphocytes), but also in pancreatic $\beta$-cells and intestinal enterocytes. This molecule inhibits the STAT1 transcription factor in the IFN signaling pathway, whereby the downregulation type I (IFNa and IFN $\beta$ ) and type II (IFNY) IFN receptors are activated. The inhibition of PTPN2 expression in pancreatic insulocytes and intestinal enterocytes leads to the activation of STAT and the subsequent formation of apoptosis through Bim proteins and the mitochondrial pathway of activation. This suggests that polymorphism of the PTPN2 gene can cause $\beta$ cell apoptosis and loss of the intestinal epithelial barrier followed by the appearance of symptoms of DMT1. Too early start of intake of cow's milk or gliadin from wheat in children, as well as the viral infections, are the most common triggers that can cause the onset of DMT1 and $\beta$-cell autoimmunity, 
caused by polymorphism of the PTPN2 gene (42, 43). Polymorphisms of this gene (rs478582, rs1893217, and rs2542151) were also identified in persons suffering from inflammatory intestinal disease, celiac disease and rheumatoid arthritis (28).

\section{Potassium voltage-gated channel subfamily J member 11 (KCNJ11)}

The KCNJ11 gene (gene for the potassium voltage channel, subfamily J, member 11) is localized on a short arm of chromosome 11 at position 15.1. This gene encodes the formation of four subunits of the hetero-octamer complex of the ATPsensitive potassium channel (KATP), while the other four subunits are encoded by the $A B C C 8$ gene. Namely, the KCNJ11 gene encodes Kir6.2 subunit (inward-rectifier potassium channel subunit) which participate in the formation of KATP pores, while the ABCC8 gene encodes the SUR1 (receptor sulphonylurea) regulatory subunits $(44,45)$.

KATP channels are transmembrane channels that are most commonly found in the plasma membrane of the $\beta$-cells of the Langer-Hans pancreatic islet. In addition to these cells, KATP channels can also be found on muscle and nerve cells. They open or close depending on the amount of blood glucose. Increasing intracellular metabolic activity leads to a change in the relationship between ATP and ADP in the cell and conditions the closure of the KATP channel. By closing these channels, depolarization of the pancreatic $\beta$-cells occurs, which is also a trigger for the secretion of insulin $(44,46)$.

Mutations of $\mathrm{KCNJ11}$ and $\mathrm{ABCC} 8$ genes are present in about $50 \%$ of patients with DMT1. These mutations prevent the closure of the KATP channel and hence the insulin secretion in response to hyperglycemia. Also, in children with this disorder, neurological disorders are observed as well. One of the most serious disorders that can occur is DEND syndrome, which is characterized by neonatal diabetes, a developmental disorder, epilepsy and later onset of speech. To date, several polymorphisms of the KCNJ11 genes which are associated with the occurrence of DMT1 are found. The most prevalent in the population are E23K, A190A, L267L, L270V, I337V, K381K and S385C $(45,47)$.

\section{(CD226)}

Platelet and $\mathbf{T}$ cell activation antigen 1

CD226 or DNAM-1 (DNAX auxiliary molecule1) is an immunoglobulin-like transmembrane glycoprotein found on plasma membranes of monocytes, macrophages, megakaryocytes, thrombocytes, NK and T-lymphocytes, as well as in some subpopulations of B-lymphocytes. This receptor participates in numerous immunological functions, such as cell signaling and adhesion, cytokine secretion, differentiation of naive T-cells, as well as proliferation and activation of cytotoxic T-lymphocytes, then migration of leukocytes to the site of infection, mastocyte degranulation, and thrombocyte aggregation. Ligands for the CD226 receptor are CD112 and CD155 (poliovirus receptor). Their binding to the receptor leads to cytotoxicity reaction (NK and T-lymphocytes) and cytokine secretion $(48,49)$.

In recent years, the CD226 gene polymorphism found at 18q22.3 is increasingly associated with the development of multiple autoimmune diseases including DMT1, rheumatoid arthritis, systemic lupus erythematosus, Grave's disease, and psoriasis. The polymorphism of this gene, with DMT1, occurs in exon 7 when cysteine is replaced by thymine (rs763361 C>T), which leads to the replacement of a glycine with serine at the site 307 (Gly307Ser). Lazano et al. (2013) have shown that by activating the CD226 receptor on T-lymphocytes, the balance between Th1, Th2 and Th17 immune responses changes. Activation of this receptor affects the increased production of proinflammatory cytokine and T-cell proliferation leading to a proinflammatory response, while its blockage affects the reduction of IL-17 secretion, indicating the potential for the use of a CD226 receptor blocker for the treatment of Th1 and Th17 autoimmune diseases $(50,51)$.

\section{Conclusion}

Although DMT1 is a disease known for more than a century, scientists still intensively research determination of its more precise etiology and genetic basis of the disease. For this purpose, the monitoring of the polymorphisms of genes for which there are already evidence of their association to DMT1, as well as the initiation of more research for testing of the new polymorphisms of the genes would provide a great contribution. Such discoveries which we could name "preventive genetics" would greatly contribute to the early detection of patients and the individualization of the therapy, which can also encourage the development of vaccine usage in patients with DMT1.

\section{Acknowledgments}

The present study was financially supported through grant from the Ministry of Education, Science and Technological Development of the Republic of Serbia (project number III 41018). The authors do not have any conflicts of interest in the present study. 


\section{References}

1. Kaufman FR. Medical management of type 1 diabetes. 6th ed. Virginia: American Diabetes Association; 2012. p 5-50.

2. Bugarin A. HLA rizični genotipovi za dijabetes tipa $1 \mathrm{u}$ oboljelih u Istočnoj Hrvatskoj [diplomski rad]. Sveučilište Josipa Jurja Strossmayera u Osijeku: Medicinski fakultet; 2015.

3. Russo L, Iafusco D, Brescianini S, Nocerino V, Bizzarri $\mathrm{C}$, Toni $\mathrm{S}$, et al. Permanent diabetes during the first year of life: Multiple gene screening in 54 patients. Diabetologia 2011;54(7):1693-701.

[CrossRef][PubMed]

4. Søvik O, Irgens HU, Molnes J, Sagen J V, Bjørkhaug $L$, Ræder $\mathrm{H}$, et al. Monogenic diabetes mellitus in Norway. Nor Epidemiol 2013;23(1):55-60. [CrossRef]

5. Ilić S. Interna medicina. 1st ed. Niš: Prosveta Niš; 2004. p 352-386.

6. Kumar V, Abbas A, Fausto N, Mitchell R. Robinsonove osnove patologije. 8th ed. Beograd: Datastatus; 2007. p 755-787.

7. Abbas A, Lichtman A, Pillai S. Cellular and molecular immunology. 9th ed. Philadelphia: ELSEVIER; 2018. p 425-434.

8. Smyth DJ, Plagnol V, Walker NM, Cooper JD, Downes $\mathrm{K}$, Yang JHM, et al. Shared and Distinct Genetic Variants in Type 1 Diabetes and Celiac Disease. N Engl J Med 2008; 359(26):2767-77. [CrossRef][PubMed]

9. Noble JA, Valdes AM. Genetics of the HLA region in the prediction of type 1 diabetes. Curr Diab Rep 2011; 11(6):533-42. [CrossRef][PubMed]

10. Bertrams J. The HLA association of insulin-dependent (type I) diabetes mellitus. Behring Inst Mitt 1984; (75):89-99. [CrossRef] [PubMed]

11. Boitard C. Pancreatic islet autoimmunity. Presse Med 2012; 41(12 P 2): e636-50. [CrossRef][PubMed]

12. Nakayama M, Abiru N, Moriyama H, Babaya N, Liu E, Miao $D$, et al. Prime role for an insulin epitope in the development of type 1 diabetes in NOD mice. Nature 2005; 435(7039):220-3. [CrossRef][PubMed]

13. Barratt BJ, Payne F, Lowe CE, Hermann R, Healy BC, Harold $D$, et al. Remapping the insulin gene/IDDM2 locus in type 1 diabetes. Diabetes 2004;53(7):1884-9. [CrossRef][PubMed]

14. Kim MS, Polychronakos C. Immunogenetics of type 1 diabetes. Horm Res 2005;64(4): 180-8. [CrossRef][PubMed]

15. So M, Elso CM, Tresoldi E, Pakusch M, Pathiraja V, Wentworth JM, et al. Proinsulin C-peptide is an autoantigen in people with type 1 diabetes. Proc Natl Acad Sci U S A 2018; 115(42):10732-7. [CrossRef][PubMed]

16. Yoon JW, Jun HS. Cellular and molecular pathogenic mechanisms of insulin-dependent diabetes mellitus. Ann N Y Acad Sci 2001;928:200-11. [CrossRef][PubMed]

17. Durinovic-Bello I. Autoimmune diabetes: the role of $T$ cells, MHC molecules and autoantigens. Autoimmunity 1998;27(3):159-77. [CrossRef][PubMed]

18. Heward J, Gordon C, Allahabadia A, Barnett AH, Franklyn JA, Gough SC. The A-G polymorphism in exon 1 of the CTLA-4 gene is not associated with systemic lupus erythematosus. Ann Rheum Dis 1999;58(3):193-5. [CrossRef][PubMed]

19. Putarek NR. Povezanost biljega polimorfizma gena HLA razreda II, CTLA-4 i PTPN22 te specifičnih autoantitijela protiv beta stanica Langerhansovih otočića $\mathrm{s}$ nastankom dijabetesa melitusa tipa $1 \mathrm{u}$ bolesnika $s$ autoimunom bolešću štitnjače [disertacija]. Sveučilište u Zagrebu: Medicinski fakultet; 2015.

20. Chang W-W, Zhang L, Yao Y-S, Su H. Association between CTLA-4 exon-1 +49A/G polymorphism and systemic lupus erythematosus: an updated analysis. Mol Biol Rep 2012;39(9):9159-65. [CrossRef][PubMed]

21. Jiang $Y$, Xia B, Jiang $L, L v M$, Guo $Q$, Chen $M$, et al. Association of CTLA-4 gene microsatellite polymorphism with ulcerative colitis in Chinese patients. Inflamm Bowel Dis 2006;12(5):369-73. [CrossRef][PubMed]

22. Almasi S, Erfani N, Mojtahedi Z, Rajaee A, Ghaderi A. Association of CTLA-4 gene promoter polymorphisms with systemic sclerosis in Iranian population. Genes Immun 2006;7(5):401-6. [CrossRef][PubMed]

23. Dilas LT, Icin T, Paro JN, Bajkin I. [Autoimmune thyroid disease and other non-endocrine autoimmune diseases]. Med Pregl 2011;64(3-4):183-7. [CrossRef][PubMed]

24. Anjos S, Polychronakos C. Mechanisms of genetic susceptibility to type I diabetes: beyond HLA. Mol Genet Metab 2004;81(3):187-95.

[CrossRef][PubMed]

25. Baniasadi V, Narain N, Goswami R, Das SN. Promoter region -318 C/ $T$ and -1661 A/G CTLA-4 single nucleotide polymorphisms and type 1 diabetes in North Indians. Tissue Antigens 2006;67(5):383-9. [CrossRef][PubMed]

26. Gloria-Bottini F, Saccucci $P$, Manca-Bitti ML, Rapini N, Verrotti A, Neri $A$, et al. Type 1 diabetes mellitus. Comparison between the association with PTPN22 genotype and the association with ACP1-ADA1 joint genotype. Diabetes Res Clin Pract 2014;106(1):e7-9. [CrossRef][PubMed]

27. Rodríguez A, Alfaro JM, Balthazar V, Pineda Trujillo N. Association analysis of PTPN22, CTLA4 and IFIH1 genes with type 1 diabetes in Colombian families. J Diabetes 2015; 7(3):402-10. [CrossRef][PubMed]

28. Sharp RC, Abdulrahim M, Naser ES, Naser SA. Genetic Variations of PTPN2 and PTPN22: Role in the Pathogenesis of Type 1 Diabetes and Crohn's Disease. Front Cell Infect Microbiol 2015;5:95. [CrossRef][PubMed]

29. Bakay M, Pandey R, Hakonarson H. Genes involved in type 1 diabetes: An update. Genes (Basel) 2013; 4(3):499-521. [CrossRef][PubMed]

30. Jermendy Á, Szatmári I, Körner A, Szabó AJ, TóthHeyn P, Hermann R. Association between interferoninduced helicase (IFIH1) rs1990760 polymorphism and seasonal variation in the onset of type 1 diabetes mellitus. Pediatr Diabetes 2018;19(2):300-4. [CrossRef][PubMed]

31. Winkler C, Lauber C, Adler K, Grallert H, Illig T, Ziegler $A G$, et al. An interferon-induced helicase (IFIH1) gene polymorphism associates with different rates of progression from autoimmunity to type 1 diabetes. Diabetes 2011;60(2):685-90. [CrossRef][PubMed]

32. Hadzija MP, Korolija M, Jemin N, Pavkovic I, Pavkovic $\mathrm{P}$, Medvidovic EP, et al. Polymorphisms in the IL-18 and IL-12B genes and their association with the clinical outcome in Croatian patients with Type 1 diabetes. Gene 2013;512(2):477-81.

[CrossRef][PubMed] 
33. Bonakdaran S, Abbaszadegan MR, Dadkhah E, Khajeh-Dalouie M. Vitamin $D$ receptor gene polymorphisms in type 1 diabetes mellitus: a new pattern from Khorasan Province, Islamic Republic of Iran. East Mediterr Health J 2012;18(6):614-9. [CrossRef][PubMed]

34. Despotovic M, Jevtovic Stoimenov T, Stankovic I, Basic J, Pavlovic D. Vitamin D Receptor Gene Polymorphisms in Serbian Patients With Bronchial Asthma: A Case-Control Study. J Cell Biochem 2017;118(11):3986-92. [CrossRef][PubMed]

35. Despotović MR. Polimorfizmi gena uključenih u inflamatorne, antioksidativne i imunoregulatorne procese kod obolelih od bronhijalne astme [disertacija]. Univerzitet u Nišu: Medicinski fakultet; 2015.

36. Eltahir Khalid K. Vitamin D receptor gene polymorphisms in Sudanese children with type 1 diabetes. AIMS Genet 2016;3(3):167-76. [CrossRef]

37. Motohashi $Y$, Yamada S, Yanagawa T, Maruyama T, Suzuki $R$, Niino $M$, et al. Vitamin $D$ receptor gene polymorphism affects onset pattern of type 1 diabetes. J Clin Endocrinol Metab 2003;88(7):3137-40. [CrossRef][PubMed]

38. Jevtovic-Stoimenov T, Cvetkovic T, Despotovic M, Basic J, Cvetkovic J, Marjanovic G, et al. The influence of TNF alpha $-308 \mathrm{G} / \mathrm{A}$ polymorphism on oxidative stress in patients with chronic lymphocytic leukemia. Leuk Res 2017;54: 66-72. [CrossRef][PubMed]

39. Jevtovic-Stoimenov T, Kocic G, Pavlovic D, Macukanovic-Golubovic L, Marjanovic G, Djordjevic V, et al. Polymorphisms of tumor-necrosis factor-alpha - 308 and lymphotoxin-alpha +250 : possible modulation of susceptibility to apoptosis in chronic lymphocytic leukemia and non-Hodgkin lymphoma mononuclear cells. Leuk Lymphoma 2008;49(11):2163-9. [CrossRef][PubMed]

40. Santin I, Eizirik DL. Candidate genes for type 1 diabetes modulate pancreatic islet inflammation and $\beta$-cell apoptosis. Diabetes Obes Metab 2013;15(S3): 71-81. [CrossRef][PubMed]

41. Hakonarson $\mathrm{H}$, Grant SFA, Bradfield JP, Marchand L, Kim CE, Glessner JT, et al. A genome-wide association study identifies KIAA0350 as a type 1 diabetes gene. Nature 2007;448(7153):591-4. [CrossRef][PubMed]

42. Rheinheimer J, Oliveira F dos S de, Canani LH, Crispim D. The rs1893217 (T/C) polymorphism in PTPN2 gene is not associated with type 1 diabetes mellitus in subjects from Southern Brazil. Arq Bras Endocrinol Metabol 2014;58(4):382-8. [CrossRef][PubMed]

43. Santin I, Moore F, Colli ML, Gurzov EN, Marselli L, Marchetti $P$, et al. PTPN2, a candidate gene for type 1 diabetes, modulates pancreatic $\beta$-cell apoptosis via regulation of the $\mathrm{BH} 3$-only protein bim. Diabetes 2011;60(12):3279-88. [CrossRef][PubMed]

44. Haghvirdizadeh $P$, Mohamed $Z$, Abdullah NA, Haghvirdizadeh $\mathrm{P}$, Haerian MS, Haerian BS. KCNJ11: Genetic Polymorphisms and Risk of Diabetes Mellitus. J Diabetes Res 2015; 2015: 908152. [CrossRef][PubMed]

45. Holstein A, Plaschke A, Stumvoll M, Kovacs P. The Glu23Lys polymorphism in KCNJ11 and impaired hypoglycaemia awareness in patients with type 1 diabetes. J Hum Genet 2005; 50(10): 530-3. [CrossRef][PubMed]

46. Edghill EL, Gloyn AL, Gillespie KM, Lambert AP, Raymond NT, Swift PG, et al. Activating Mutations in the KCNJ11 Gene Encoding theATP-Sensitive $\mathrm{K} / \mathrm{h}$ Channel Subunit Kir6.2 Are Rare in Clinically Defined Type 1 Diabetes Diagnosed Before 2 Years. Diabetes 2004; 53(11):2998-3001. [CrossRef][PubMed]

47. Cho JH, Kang E, Lee BH, Kim GH, Choi JH, Yoo HW. DEND Syndrome with Heterozygous KCNJ11 Mutation Successfully Treated with Sulfonylurea. J Korean Med Sci 2017;32(6): 1042-5. [CrossRef][PubMed]

48. Abu El-Ella SS, Khattab ESAEH, El-Mekkawy MS, ElShamy AA. CD226 gene polymorphism (rs763361 C>T) is associated with susceptibility to type 1 diabetes mellitus among Egyptian children. Arch Pediatr 2018;25(6):378-82. [CrossRef][PubMed]

49. Mattana TCC, Santos AS, Fukui RT, Mainardi-Novo DTO, Costa VS, Santos RF, et al. CD226 rs763361 is associated with the susceptibility to type 1 diabetes and greater frequency of GAD65 autoantibody in a Brazilian cohort. Mediators Inflamm 2014;2014: 694948. [CrossRef][PubMed]

50. Xi JS, Nie CL, Wang J, Ma Y, Ma AH. Association of CD226 polymorphisms with the susceptibility to type 1 diabetes in Chinese children. Genet Mol Res 2015; 14(4):15249-55. [CrossRef][PubMed]

51. Zeng $H$, Liu Q, Guan Z, Zhao F, Wang $H$, Chen L. Correlation between CD226 polymorphism ( rs763361 ) and the susceptibility of lung cancer in nonsmoking Chinese population. Int J Clin Exp Pathol 2016; 9(3):3905-11. [CrossRef] 


\title{
UDRUŽENOST GENSKIH POLIMORFIZAMA SA POJAVOM DIABETES MELITUSA TIP 1
}

\author{
Maja Jović1, Vesna Cvetković3 ${ }^{1}$ Milena Despotović2 ${ }^{2}$ Tatjana Jevtović-Stoimenov ${ }^{1,2}$
}

\author{
${ }^{1}$ Univerzitet u Nišu, Medicinski fakultet, Naučnoistraživački centar za biomedicinu, Niš, Srbija \\ 2Univerzitet u Nišu, Medicinski fakultet, Katedra za biohemiju, Niš, Srbija \\ ${ }^{3}$ Klinika za dečje interne bolesti, Klinički centar Niš, Srbija \\ Kontakt: Maja Jović \\ Bul. dr Zorana Đinđića 81, 18000 Niš, Srbija \\ E-mail:drmajaj@gmail.com
}

Jedan od najčešćih endokrinih poremećaja kod dece i adolescenata, Diabetes mellitus (DM), predstavlja hroničnu, poligensku i kompleksnu bolest. Na osnovu etiologije, DM se može podeliti na dve osnovne grupe: Diabetes mellitus tip 1 (DMT1) i Diabetes mellitus tip 2 (DMT2). DMT1 predstavlja oboljenje posredovano imunološkim mehanizmima, u čijoj osnovi je autoimunska destrukcija insulocita od strane imunoreaktivnih T-ćelija i antitela, što dovodi do insulinske rezistencije i sindroma hiperglikemije.

Nekoliko različitih molekularnih mehanizama doprinose uništavaju $\beta$-ćelija Langerhansovih ostrvaca, kao što su: produkcija autoantitela usmerenih protiv antigena na insulocitima, liza Langerhansovih ostrvaca posredovana citotoksičnim CD8+ T limfocotitima, lokalna produkcija citokina (TNF i IL-1) od strane makrofaga, koji oštećuju insulocite, i reakcije kasne preosetljivosti posredovane CD4+ Th1 limfocitima.

Najvažniji geni, koji pokazuju visok stepen povezanosti sa DMT1 nalaze se u regionu koji kodira MHC (major histocompatibility complex) molekule I i II klase. Međutim, postoje veoma čvrsti dokazi o povezanosti i drugih gena (van MHC genskog područja) sa ispoljavanjem DMT1. To su: gen za insulin (INS), gen za protein 4 vezan na citotoksični T limfocit (CTLA4), gen za protein tirozin fosfatazu - 22 (PTPN22), gen za protein tirozin fosfatazu - 2 (PTPN2), gen za protein lecitin tipa C (CLEC16A, KIAA0350), gen za receptor a interleukina 2 (IL2RA/CD25), genska regija za interferon indukovanu helikazu (IFIH1), KCNJ11, CD226, gen za receptor vitamina $D$ (VDR), geni za faktor tumorske nekroze (TNF) i limfotoksin-a (LTA). Pored ovih gena, istraživači i dalje tragaju za drugim genima koji su povezani sa pojavom i ekspresijom DMT1.

Acta Medica Medianae 2020;59(1):125-132.

Ključne reči: Diabetes mellitus tip 1, autoimunska endokrinopatija, polimorfizmi non-HLA gena 